\title{
NOTARIUSZ JAKO INSTYTUCJA OBOWIĄZANA W ROZUMIENIU USTAWY O PRZECIWDZIAŁANIU PRANIU PIENIĘDZY ORAZ FINANSOWANIU TERRORYZMU (OMÓWIENIE NIEKTÓRYCH ZAGADNIEŃ)
}

\section{Wstęp}

W dniu 12 lipca 2018 r. weszło w życie nowe uregulowanie prawne w postaci ustawy z dnia 1 marca 2018 r. o przeciwdziałaniu praniu pieniędzy oraz finansowaniu terroryzmu (dalej: $n U o P)^{1}$. Stanowi ono odzwierciedlenie, a jednocześnie polską implementację rozwiązań przyjętych w tzw. IV dyrektywie AML-owej (dalej: IV DAML) ${ }^{2}$. W przedmiotowej ustawie jako instytucje obowiązane ujęto m.in. w kategorii zawody prawnicze notariuszy. Dotychczasowe rozwiązanie pozwala na skonkretyzowanie odpowiedzialności za realizowanie określonych czynności (lub ich brak) także na innych osobach realizujących zakres czynności „jak notariusz". Niemniej rzeczywiście, gdy przyjęto w nUoP nie tylko kryterium podmiotowe, ale także przedmiotowe, powinno być ono $\mathrm{w}$ pełni zrealizowane również $\mathrm{w}$ stosunku do innych podmiotów, poza notariuszami,

* Dr, młodszy inspektor w stanie spoczynku, radca prawny (OIRP Warszawa); e-mail: sulawezi.mk@onet.eu, https://orcid.org/0000-0003-3074-1355.

1 Ustawa z dnia 1 marca 2018 r. o przeciwdziałaniu praniu pieniędzy oraz finansowaniu terroryzmu, tekst jednolity: Dz. U. z 2020 r. poz. 971 z późn. zm.

2 Dyrektywa Parlamentu Europejskiego i Rady (UE) 2015/849 z dnia 20 maja 2015 r. w sprawie zapobiegania wykorzystywaniu systemu finansowego do prania pieniędzy lub finansowania terroryzmu, zmieniająca rozporządzenie Parlamentu Europejskiego i Rady (UE) nr 648/2012 i uchylająca dyrektywę Parlamentu Europejskiego i Rady 2005/60/WE oraz dyrektywę Komisji 2006/70/WE (tekst mający znaczenie dla EOG), Dz. Urz. UE L141/73 z 5.6.2015. 
w zakresie działalności których pozostaje też wykonywanie tych przedmiotowych czynności notarialnych zgodnie z ustawą kompetencyjną i innymi przepisami. Kwestia ta powinna pozostać do rozstrzygnięcia przez ustawodawcę przy kolejnej nowelizacji ustawy. Należy pamiętać także o tym, aby przepisy implementacyjne pozostawały w zgodności z prawem Unii Europejskiej. Wydaje się jednak, że rozszerzenie podmiotowego katalogu pozostaje bardziej związane z (wewnętrznym, krajowym uregulowaniem) tzw. „uwolnieniem zawodów prawniczych”, co, jak należy przypuszczać, nie było brane pod uwagę podczas tworzenia przepisów IV DAML. Z tego też wynikają konsekwencje uzyskania aktualnego kształtu przepisów nUoP, zawężających podmiot obowiązany jedynie do notariuszy, i nieuwzględnienie , asesora notarialnego", ,"zastępcy notariusza”, "notariusza emerytowanego" czy "innego notariusza”. Dodatkowo w przedmiotowej publikacji zostanie przedstawionych szereg uwag związanych z kwestią, kiedy notariusz staje się instytucją obowiązaną, kolejno związanych z rodzajem wykonywanych obowiązków przez notariusza wynikających z nUoP, a także przedstawione zostaną uwagi odnoszące się do zakresu relacji zachodzących pomiędzy notariuszem a Generalnym Inspektorem Informacji Finansowej (dalej: GIIF).

W art. 2 ust. 1 pkt 13, 13a i 14 nUoP wskazano rodzaje zawodów prawniczych posiadających jednocześnie status instytucji obowiązanych. Notariuszom poświęcony jest pkt 13 i 13a powyższego przepisu. Przy czym, oprócz nazwania tych zawodów, przedstawiono także zakres zadaniowo-merytoryczny, w jakim obszarze są one instytucjami obowiązanymi, a tym samym zobowiązane ustawowo do wykonywania określonych czynności. Należy zauważyć, że w IV DAML, oprócz nazwania, notariusze zostali potraktowani jak „inne wolne zawody prawnicze”. Tę grupę zawodową wymieniono w następujących jednostkach redakcyjnych IV DAML: art. 2 ust. 1 pkt 3 lit. b, art. 14 ust. 4 drugi akapit, art. 34 ust. 2. Nie pozostawia wątpliwości to, że notariusz jest zawodem prawniczym (nie tylko w rozumieniu IV DAML) o wysokim poziomie zaufania publicznego, ale także podmiotem uczestniczącym $\mathrm{w}$ obrocie prawnym i gwarantującym prawidłowość takiego obrotu. Stąd też umieszczenie tej kategorii zawodowej $\mathrm{w}$ dyrektywie poświęconej przeciwdziałaniu praniu pieniędzy oraz finansowaniu terroryzmu należy uznać za całkowicie zrozumiałe. Jednocześnie trzeba zauważyć, że podobne procedury dotyczące notariuszy umieszczono również w Poradniku dla sektora zawodów prawniczych wydanym przez 
$\mathrm{FATF}^{3}$. Ponadto należy zaznaczyć, że nUoP stanowi akt implementacji do polskiego porządku prawnego rozwiązań zawartych w IV DAML, a więc nieujęcie określonych podmiotów jako obowiązanych do wykonywania prawem określonych działań i współpracy z jednostką analityki finansowej (JAF) mogłoby narazić polskiego ustawodawcę na zarzut niezgodności przygotowanej regulacji z prawem europejskim ${ }^{4}$. Dodatkowo warto zwrócić uwagę na to, że w aktualnym stanie prawnym znacznie ograniczono zakres merytorycznych działań notariuszy, który polega (na podstawie własnej aktywności) na informowaniu do JAF. Prezentowana konstrukcja wpływa na kształt realizowania obowiązków w zakresie przeciwdziałania praniu pieniędzy oraz finansowaniu terroryzmu (AML/CFT ${ }^{5}$ ) przez notariuszy w systemie, którego podstawą jest nUoP. Istotne relacje pomiędzy notariuszem jako instytucją obowiązaną a GIIF zostały więc uregulowane głównie w dwóch miejscach nUoP, tj. w art. 2 ust. 1 pkt 13 (w tym przypadku obszar przekazywania informacji dotyczy czynności notarialnych dokonanych $\mathrm{w}$ formie aktu notarialnego w zakresie przedmiotowym wskazanym $\mathrm{w}$ tym przepisie), a także $\mathrm{w}$ zakresie czynności, o których mowa w art. 79 pkt 6a ustawy z dnia 14 lutego 1991 r. Prawo o notariacie ${ }^{6}$ oraz $\mathrm{w}$ art. 76 ust. 2 nUoP, tj. przekazywania na żądanie GIIF również informacji i dokumentów w zakresie innych czynności notarialnych niż wymienionych w przepisie art. 2 ust. 1 pkt 13 nUoP.

3 FATF (Financial Action Task Force) jest instytucją międzyrządową, mającą na celu wypracowywanie i określanie standardów w dziedzinie przeciwdziałania praniu pieniędzy oraz finansowaniu terroryzmu. Zob. Public Consultation on the Draft Risk-Based Approach Guidance for Legal Professionals, Accountants and Trust and Company Service Providers, oficjalna strona FATF: https://www.fatf-gafi.org/publications/fatfgeneral/documents/ public-consultation-guidance-tcsp.html [dostęp: 2.04.2019 r.].

4 Krytycznie w odniesieniu do nakładanych na notariuszy obowiązków w zakresie funkcjonowania poprzedniej ustawy z dnia 16 listopada 2000 r. o przeciwdziałaniu praniu pieniędzy oraz finansowaniu terroryzmu (Dz. U. z 2017 r. poz. 1049, Dz. U. z 2018 r. poz. 650, 1075) zob. J. Holocher, Bezpieczeństwo obrotu prawno-finansowego. Obowiazki notariusza w świetle ustawy o przeciwdziałaniu praniu pieniędzy oraz finansowaniu terroryzmu, Kwartalnik Prawa Publicznego 2015, t. 13, nr 2, s. 7 i nn.

5 AML/CFT - Anti Money Laundering / Counter Financing of Terrorism.

6 Ustawa z dnia 14 lutego 1991 r. - Prawo o notariacie, tekst jednolity: Dz. U. z 2020 r. poz. 1192. Oznacza to dodatkową potrzebę realizowania obowiązku w zakresie prowadzenia rejestru akcjonariuszy prostych spółek akcyjnych oraz podejmowania związanych z tym czynności określonych ustawą (przepis wszedł w życie z dniem 1.03.2020 r.). 
Należy zauważyć, że za każdym razem IV DAML stanowi o „notariuszu" jako podmiocie zobowiązanym, nie zaś o innych rodzajach przypadków „bycia notariuszem” przez podmiot niespełniający tego warunku zawodowego. W prawie polskim występuje dodatkowo pojęcie "asesora notarialnego" oraz "zastępcy notariusza”, "notariusza emerytowanego" czy „innego notariusza”. Jednocześnie art. 2 ust. 1 pkt 3 lit. b wynikający z IV DAML nie przewiduje wprowadzenia „opcji narodowej” w tym zakresie. Ze względu na dopełnienie przedmiotowe - aktualnie dotyczy to tylko czynności dokonywanych w formie aktu notarialnego - z zakresu rozważań trzeba wyłączyć de facto aplikanta notarialnego (za wyjątkiem protokołów, o których mowa w art. 79 pkt 4 ustawy Prawo o notariacie W zw. z art. 22a $\S 1$ tejże ustawy) ${ }^{7}$. W aktualnym stanie prawnym mowa jest jedynie o „notariuszu”, nie zaś o „innej osobie”, a ponadto należy zważyć na to, że odpowiedzialność za dokonanie w kancelarii czynności notarialnych podlegających obowiązkowi informacyjnemu do GIIF przez inną osobę niż notariusza (np. zastępcę notarialnego) wprost obciąża samego notariusza prowadzącego kancelarię lub wszystkich notariuszy bądź wyznaczonego notariusza, gdy kancelaria prowadzona jest w ramach spółki cywilnej albo partnerskiej. Stąd też tak ważne jest nie tylko systematyczne wywiązywanie się z obowiązków określonych w nUoP, ale także precyzyjne ustanowienie wewnętrznej procedury przeciwdziałania określającej odpowiedzialność danej osoby - tj. notariusza wykonującego czynności notarialne podlegające raportowaniu do GIIF (wymienionej konkretnie z imienia i nazwiska wraz z podaniem innych danych identyfikacyjnych). Ponadto wewnętrzna procedura przeciwdziałania nie jest prawem prezentującym wewnętrzny regulamin prowadzenia kancelarii notarialnej, lecz dokumentem opartym na przepisach innej niż ustawa Prawo o notariacie ustawie i zawiera zakres obowiązków oraz sposoby ich wypełniania przez notariusza i pracowników kancelarii w zakresie podejmowania określonych zachowań mieszczących się w obszarze AML/CFT. Notariusz $\mathrm{w}$ ramach $\mathrm{nUoP}$ jest rozliczany $\mathrm{z}$ tych obowiązków i zachowań, nie zaś z prowadzenia kancelarii notarialnej w zakresie określonym w ustawie Prawo o notariacie i przepisach wykonawczych (z wyjątkiem zwolnienia $\mathrm{z}$ zachowania $\mathrm{w}$ tajemnicy udostępniania informacji na podstawie nUoP). Należy wskazać, że aktualnie wewnętrzna procedura przeciwdziałania

7 K. Maj, Obowiązki notariusza w nowej ustawie o przeciwdziałaniu praniu pieniędzy i finansowaniu terroryzmu, Krakowski Przegląd Notarialny 2018, t. 3, nr 1, s. 84. 
nie została przez ustawodawcę obwarowana formą pisemną. Nie oznacza to, że procedura ta nie powinna przybrać jakiejś formy (np. pisemnej, elektronicznej lub złożenia jedynie podpisów elektronicznych poświadczających zapoznanie się z nią). W przypadku funkcjonowania kancelarii notarialnych, których jednym z założeń jest stosowanie reguł formalnych na potrzeby bezpieczeństwa obrotu, wydaje się, że powinna ona przybrać formę tożsamą z wymaganymi również $\mathrm{w}$ relacjach z pracownikami kancelarii czy innymi notariuszami (a także formami ustalanymi na podstawie przepisów ustawy Prawo o notariacie). Podstawowym założeniem jest to, by ją sporządzić, ten fakt będzie podlegał też czynnościom kontrolnym GIIF i prezesów sądów apelacyjnych $\mathrm{w}$ zakresie przestrzegania przepisów nUoP. Jednocześnie trzeba zauważyć, że zgodnie z treścią art. 52 ust. 1 nUoP instytucje obowiązane zapewniają udział osób wykonujących obowiązki związane z przeciwdziałaniem praniu pieniędzy oraz finansowaniu terroryzmu w programach szkoleniowych dotyczących realizacji tych obowiązków. Tak więc w ramach kancelarii notarialnej należałoby rozstrzygnąć, czy wszyscy, czy też jedynie niektórzy pracownicy będą podlegali obowiązkowi edukacyjnemu w zakresie AML/CFT w związku z obowiązkiem wskazanym powyżej. Powinno to także zostać jasno określone przez kierującego kancelarią, zwłaszcza gdy notariusz będzie chciał ustalić zasady realizacji niektórych czynności notarialnych przez inne osoby i powiązać je z przestrzeganiem obowiązków ustalonych w nUoP.

W zakresie zawartego w nUoP określenia „notariusze” na gruncie prawa polskiego ma zastosowanie ustawa Prawo o notariacie. Art. 11 ustawy stanowi o tym, kto może być notariuszem. Istotne z punktu widzenia wypełniania obowiązków z nUoP jest to, kiedy dana osoba może być uznana jako notariusz. Zgodnie z art. $10 \S 1$ ustawy Prawo o notariacie notariusza, na wniosek osoby zainteresowanej, powołuje i wyznacza siedzibę jego kancelarii Minister Sprawiedliwości, po zasięgnięciu opinii rady właściwej izby notarialnej. Jednocześnie zgodnie z treścią art. $14 \S 1$ przywołanej ustawy notariusz jest obowiązany w ciągu dwóch miesięcy od zawiadomienia o powołaniu uruchomić kancelarię i zgłosić informację o tym fakcie Ministrowi Sprawiedliwości. W razie nieuruchomienia kancelarii w tym terminie powołanie traci moc, okoliczność tę stwierdza Minister Sprawiedliwości. Zatem notariusz staje się instytucją obowiązaną z chwilą posiadania powołania odebranego od Ministra Sprawiedliwości i (łącznie/iunctim) spełnienia warunku uruchomienia kancelarii w wyznaczonym terminie. Minister Sprawiedliwości nie może także w decyzji o powołaniu 
notariusza wskazać innej lokalizacji kancelarii niż ta, którą osoba zainteresowana podała we wniosku złożonym w trybie art. 13 ustawy Prawo o notariacie. Minister Sprawiedliwości, powołując notariusza i wyznaczając siedzibę jego kancelarii w oparciu o przepis art. $10 \S 1$ rzeczonej ustawy, związany jest bowiem wskazaniem przez osobę zainteresowaną lokalu przewidzianego do prowadzenia kancelarii we wniosku złożonym na podstawie art. 13 tej ustawy ${ }^{8}$. Przepisy ustawy Prawo o notariacie nie określają ani wymagań co do lokalu przyszłej kancelarii notarialnej, ani też kryteriów jego lokalizacji. Jedynym ograniczeniem ustanowionym w ustawie jest zakaz prowadzenia więcej niż jednej kancelarii (art. 4 ustawy Prawo o notariacie) $)^{9}$. Ponadto ustawa wskazuje, że kilku notariuszy może prowadzić jedną kancelarię na zasadach spółki cywilnej lub partnerskiej (art. 4 §3). Wówczas jednak każdy z notariuszy dokonuje czynności notarialnych we własnym imieniu i ponosi odpowiedzialność za czynności przez siebie dokonane. Tak więc w przypadku prowadzenia kancelarii na zasadach spółki cywilnej istotne pozostaje przystąpienie „nowego notariusza” do tej spółki. Przystąpienie nowej osoby do spółki odbywa się przede wszystkim poprzez złożenie zgodnych oświadczeń woli przez dotychczasowych wspólników oraz przez osobę, która chce przystąpić do tego rodzaju spółki (art. 860-875 Kodeksu cywilnego; dalej: K.c.). Przepisy K.c. nakładają wymóg, aby umowę spółki cywilnej zawierać w formie pisemnej. Niezbędnymi elementami tej umowy jest określenie: stron umowy (czyli przyszłych wspólników spółki cywilnej), celu gospodarczego, działań podejmowanych przez wspólników dla zrealizowania celu gospodarczego (wspólne prowadzenie kancelarii notarialnej). Tym samym spółka cywilna staje się określonym prawnie „nośnikiem” czy „platformą” organizacyjno-prawną dla powstania kancelarii, w której swoje czynności zawodowe będą wykonywali notariusze. Dlatego też do urzeczywistnienia się bycia instytucją obowiązaną przez notariusza niezbędne jest zorganizowanie własnej kancelarii lub przystąpienie bądź powołanie nowej spółki cywilnej, w ramach której będzie określony cel wykonawczy - prowadzenie kancelarii przez notariuszy. Należy zaznaczyć, że forma pisemna wymagana jest do zmian umowy spółki, w tym także do przystąpienia nowego

8 Wyrok NSA z dnia 8 stycznia 2019 r., II GSK 4441/16, http:/ / orzeczenia.nsa.gov. pl/doc/81B0822860 [dostęp: 20.03.2019 r.].

9 Wyrok NSA z dnia 27 września 2018 r., II GSK 2831/16, http:/ / orzeczenia.nsa.gov. pl/doc/E7B22AC058 [dostęp: 20.03.2019 r.]. 
wspólnika. W przypadku kiedy w skład majątku spółki wchodzi nieruchomość (prawo użytkowania wieczystego), wówczas z przystąpieniem łączą się czynności notarialne związane z obrotem nieruchomościami. Pojawienie się nowego wspólnika w spółce powoduje bowiem, że zmienia się krąg osób uprawnionych do majątku spółki, w tym także do stanowiących jej własność nieruchomości. Z kolei obrót nieruchomościami w Polsce może się odbywać jedynie przy zastosowaniu aktu notarialnego ${ }^{10}$. Konsekwencje niezachowania formy aktu notarialnego są bardzo poważne wprawdzie poglądy sądów w tym zakresie się różnią, ale często wskazują one nawet na nieważność przystąpienia wspólnika do spółki. Rodzi to wiele kłopotów, przede wszystkim jeśli wspólnicy zdecydują się rozwiązać spółkę i podzielić jej majątek. Dochodzą do tego liczne komplikacje w odniesieniu do Zakładu Ubezpieczeń Społecznych i Urzędu Skarbowego oraz odpowiedzialność wobec klientów, nawet z uwzględnieniem nieważności czynności prawnej. Sytuacja taka oczywiście może mieć miejsce w przypadku „wniesienia” przez jednego lub kilku notariuszy aktywów w postaci nieruchomości (np. mieszkania, w którym będą wykonywane czynności kancelarii notarialnej) lub gdy już w chwili przystąpienia przez „nowego notariusza” przystąpi on do takiej spółki cywilnej innych notariuszy bądź kiedy sam wniesie do spółki aktywa w postaci nieruchomości. Z chwilą zakończenia formalno-pisemnej procedury zawiązania spółki cywilnej lub przystąpienia do niej nowego wspólnika dany notariusz może identyfikować się z kancelarią, której istnienie i uruchomienie jest niezbędne do uznania notariusza jako instytucji obowiązanej z przynależnymi mu obowiązkami wynikającymi z nUoP. Tym samym kancelaria zostaje „uruchomiona" i powinna zostać zgłoszona do Ministra Sprawiedliwości. Oczywiste jest, że wiążą się z tym dodatkowe kwestie łączone z uzyskaniem odpowiedniego technicznego zaplecza do wykonywania zawodu. Wskazane w art. 10 § 1 ustawy Prawo o notariacie stwierdzenie, że: „wyznacza siedzibę jego kancelarii Minister Sprawiedliwości (MS), na wniosek osoby zainteresowanej", może sugerować, że notariusz sam z siebie dokona ustanowienia odpowiedniego miejsca do wykonywania zawodu notariusza lub jeszcze przed „powołaniem” zawrze wstępną umowę spółki cywilnej czy partnerskiej i załączy te dokumenty do wniosku skierowanego do Ministra Sprawiedliwości. Niemniej na oficjalnej stronie Ministerstwa

10 Zob. W.Studziński, Przystapienie do spótki cywilnej, https://mojafirma.infor.pl/spolki/ spolki/spolka-cywilna/691532,Przystapienie-do-spolki-cywilnej.html [dostęp: 20.03.2019 r.]. 
Sprawiedliwości brak jest $\mathrm{w}$ tym zakresie informacji. Tym samym można rozpatrywać pewne dodatkowe kwestie. Związane są one z tym, że zapis: „kilku notariuszy może prowadzić jedną kancelarię na zasadach spółki cywilnej lub partnerskiej" sugeruje, że najpierw trzeba zostać notariuszem, aby prowadzić wspólnie z innymi notariuszami kancelarię. Oznacza to, że w zakresie „wyznaczenia siedziby” przez Ministra Sprawiedliwości na wniosek zainteresowanego to notariusz powinien wskazać siedzibę kancelarii, skoro później jest mowa o poinformowaniu Ministra Sprawiedliwości o „uruchomieniu” kancelarii. Zatem elementem uruchomienia kancelarii będzie zapewnienie własnej siedziby kancelarii, przystąpienie do spółki cywilnej, której celem jest prowadzenie kancelarii przez kilku notariuszy czy też przystąpienie do spółki partnerskiej na zasadach określonych w Kodeksie spółek handlowych (dalej: K.s.h.) ${ }^{11}$ oraz umowie spółki. Ministerstwo Sprawiedliwości przyjęło, że osoby ubiegające się o powołanie na stanowisko notariusza, już w dacie złożenia wniosku do Ministra Sprawiedliwości, muszą wskazać lokal, w którym będzie prowadzona kancelaria notarialna. Związane jest to z koniecznością ponoszenia dodatkowych kosztów utrzymania lokalu (koszty eksploatacyjne, czynsz najmu) ${ }^{12}$. Wydaje się, że Ministerstwo Sprawiedliwości sugeruje, że wskazanie lokalu jest jednym z istotnych elementów uruchomienia kancelarii. Nie dopuszcza się niejako „wirtualnego” jej uruchomienia. Niemniej „wskazanie lokalu" będzie konsekwencją osobistego ustalenia miejsca dla swojej kancelarii przez notariusza, zawarcia z innymi notariuszami np. umowy przedwstępnej przystąpienia do spółki cywilnej czy spółki partnerskiej. W takim przypadku kwestie formalne także powinny być dopełnione, głównie z zachowaniem formy pisemnej. Jednakże stwierdzenie „wskazanie lokalu” kojarzone powinno być nie tyle z umowami przedwstępnymi, co z potrzebą fizycznego wykonywania czynności notarialnych, a tym samym rozpoczęcia lub współponoszenia kosztów eksploatacji tego lokalu, a także spełnienia wszystkich wymogów formalnych prawidłowego rozpoczęcia wykonywania obowiązków wobec klientów ${ }^{13}$.

11 Ustawa z dnia 15 września 2000 r. - Kodeks spółek handlowych, tekst jednolity: Dz. U. z 2020 r. poz. 1526, zwłaszcza przepisy art. 9 i Działu II Spółka partnerska, rozdz. 1.

12 Pismo Departamentu Zawodów Prawniczych i Dostępu do Pomocy Prawnej Ministerstwa Sprawiedliwości z dnia 6 czerwca 2014 r. skierowane do prezesa Rady Izby Notarialnej w Krakowie (znak DZP-IV-620-84/14), s. 1.

13 Notariusz, jako instytucja obowiązana, podlega również obowiązkowi określonemu w art. 77 nUoP. Wiąże się on z potrzebą wypełnienia formularza identyfikacyjnego dla 
Tak więc pomiędzy odebraniem powołania a formalnym wystąpieniem z poinformowaniem Ministra Sprawiedliwości (do dwóch miesięcy, musi się zakończyć najpóźniej w ostatnim dniu tego terminu) będzie miał miejsce swoisty stan „kancelarii w organizacji” lub też „kancelarii w uruchomieniu". Niemniej to notariusz, a nie kancelaria jest instytucją obowiązaną. Tym samym to na notariuszu $\mathrm{z}$ chwilą powołania spoczywają obowiązki. Dlatego też, gdy nie jest on w pełni „uprawniony zawodowo" (nie posiada uruchomionej kancelarii), nie powinien podejmować tych czynności notarialnych, z których informacje należałoby standardowo, w ramach obowiązków instytucji obowiązanej, przesłać do GIIF, ale także tych czynności, które stanowiłyby odpowiedź na żądanie GIIF określone w art. 76 ust. 2 nUoP. Elementem niezbędnym z ustawy Prawo o notariacie jest uruchomienie kancelarii w celu wykonywania czynności zawodowych. Jak zauważyło Ministerstwo Sprawiedliwości, proces dochodzenia do uzyskania pełnych uprawnień zawodowych notariusza jest kilkuetapo$\mathrm{wy}^{14}$. Samo odebranie decyzji w przedmiocie powołania na stanowisko notariusza nie może skutkować uzyskaniem uprawnienia do dokonywania we własnym imieniu, jako notariusz, czynności notarialnych. Jednocześnie Ministerstwo wskazało, że notariusz, którego powołano, nie może żądać przedłużenia terminu określonego w art. 14 § 1 ustawy Prawo o notariacie w celu pozostawienia mu okresu "do namysłu”, czy ma wolę uruchomienia kancelarii. Wyznaczony $\mathrm{w}$ tym zakresie termin ma charakter proceduralny ${ }^{15}$. Jest to całkowicie zrozumiałe z punktu widzenia wykonywania zawodu notariusza, który nie może stwarzać sytuacji niepewności, gdyż samo wykonywanie tego zawodu i realizowanie czynności notarialnych posiada w sobie warstwę porządkującą i mającą zapewniać pewność oraz bezpieczeństwo obrotu różnego rodzaju aktywami i dokumentami. Ponadto nie jest możliwe, by czynności notarialne ze względu na opieszałość

wykonania po raz pierwszy określonego w ustawie obowiązku. Formularz identyfikujący instytucję obowiązaną zawiera m.in. dane w postaci adresu siedziby lub adresu prowadzenia działalności. Tym samym odpowiednie i właściwe wskazanie lokalu pozostaje także ważne dla zidentyfikowania „nowego notariusza” - jako instytucji obowiązanej - przez GIIF. Kwestia identyfikacji może, ale nie musi być tożsama czasowo z terminem uruchomienia kancelarii.

14 Pismo Departamentu Zawodów Prawniczych i Dostępu do Pomocy Prawnej Ministerstwa Sprawiedliwości z dnia 6 czerwca 2014 r. skierowane do prezesa Rady Izby Notarialnej w Krakowie..., s. 1.

15 Tamże, s. 2. 
uruchamiania kancelarii były (lub nie) odnotowywane w jakichś tymczasowych repozytoriach prowadzonych przez notariusza. Należy także zważyć, że notariusz jako instytucja obowiązana podlega kontroli ze strony GIIF oraz na podstawie art. 130 ust. 2 pkt 1 lit. d nUoP - prezesom sądów apelacyjnych. Konsekwencją niewykonania określonych obowiązków mogą być kary administracyjne, a na podstawie art. 156 i 157 nUoP - odpowiedzialność karna. Dotyczy ona także kwestii niedopełnienia obowiązku przekazania GIIF zawiadomienia o okolicznościach, które mogą wskazywać na podejrzenie popełnienia przestępstwa prania pieniędzy lub finansowania terroryzmu, czy też przekazywania GIIF nieprawdziwych lub zatajania prawdziwych danych dotyczących transakcji, rachunków czy osób.

Kancelaria notarialna może być prowadzona także w postaci spółki partnerskiej. Regulacje w zakresie prowadzenia tej formy działalności umieszczone zostały w K.s.h. ${ }^{16}$ Spółka partnerska to spółka osobowa utworzona przez wspólników (partnerów) w celu wykonywania wolnego zawodu w spółce prowadzącej przedsiębiorstwo pod własną firmą. Może być zawiązana w celu wykonywania więcej niż jednego wolnego zawodu, chyba że ustawa stanowi inaczej. Partnerami w spółce mogą być wyłącznie osoby fizyczne, uprawnione do wykonywania wolnych zawodów, w tym notariusze, określonych w art. 88 K.s.h. Umowa spółki partnerskiej powinna być zawarta na piśmie pod rygorem nieważności. Co istotne dla rozpoczęcia działalności w postaci kancelarii notarialnej - spółka powstaje z chwilą wpisania do rejestru. Przystąpienie nowego partnera do spółki partnerskiej wiąże się z koniecznością zmiany umowy spółki oraz podjęcia kilku istotnych kroków. Należy wówczas dopełnić: podjęcia uchwały o wyrażeniu zgody na przystąpienie partnera na określonych warunkach, złożenia oświadczenia przez przystępującego partnera o przystąpieniu do spółki ze wskazaniem warunków, na jakich przystępuje, zmiany umowy spółki w formie pisemnej, przyjęcia tekstu jednolitego umowy oraz zgłoszenia zmiany umowy spółki do rejestru w wymaganej formie. Nowym partnerem spółki może zostać jedynie osoba posiadająca uprawnienia do wykonywania wolnego zawodu. Trzeba również podkreślić, że nowy partner odpowiada za zobowiązania spółki powstałe przed dniem jego przystąpienia całym swoim majątkiem ${ }^{17}$. Konsekwencją wskazanych wyżej

16 Ustawa z dnia 15 września 2000 r. - Kodeks spółek handlowych.

17 https://e-konsultantprawny.pl/pl/wiki/page/przystapienie-nowego-partnera-do-spolki-partnerski/ [dostęp: 4.03.2019 r.]. 
warunków jest także formalne dokonanie zmiany w Krajowym Rejestrze Sądowym (KRS) w zakresie przystąpienia nowego wspólnika-notariusza do już funkcjonującej spółki partnerskiej. Tym samym miejscem wypełniania obowiązków notariusza będzie lokal ustalony w ramach spółki partnerskiej jako siedziba kancelarii notarialnej. Wpis do KRS polega na wprowadzeniu do systemu teleinformatycznego danych zawartych w postanowieniu sądu rejestrowego niezwłocznie po jego wydaniu. Wpis jest dokonany z chwilą zamieszczenia danych w KRS (art. 20 ust. 1 i 1 b ustawy o $\mathrm{KRS}^{18}$ ). Wpis do rejestru wymaga uprawomocnienia się. W sprawach, $\mathrm{w}$ których postanowienia sądu rejestrowego są skuteczne lub wykonalne z chwilą uprawomocnienia, wraz z wpisem zamieszcza się wzmiankę o jego nieprawomocności. Następnie datę uprawomocnienia wpisuje się z urzę$\mathrm{du}$, a wpis ten nie podlega ogłoszeniu. Konsekwentnie więc osoba, która na mocy przepisów ustawy Prawo o notariacie nie uzyskuje statusu notariusza, nie jest również instytucją obowiązaną $\mathrm{w}$ rozumieniu nUoP. Wykonywanie czynności notarialnych bez uprawnienia, w takim przypadku, jest działaniem nie tylko na szkodę klienta, prawidłowości obrotu prawnego, ale także na szkodę GIIF. Ponadto mając na uwadze różnorodny sposób prowadzenia kancelarii oraz różny status osób w niej zatrudnionych, notariusz z pewnością będzie odpowiedzialny za realizację obowiązków wynikających z nUoP i do niego też będzie należało, wobec realizacji tych obowiązków, usankcjonowanie organizacyjne i zadaniowe wewnętrznego postępowania innych osób pracujących $\mathrm{w}$ ramach działalności kancelarii.

Do omówienia pozostają także kwestie związane z tym, czy inna osoba (w tym inny notariusz, zastępca notarialny) może być uznana za instytucję obowiązaną w określonych okolicznościach. Jak zauważa K. Maj, wobec jasnego brzmienia normy instytucją obowiązaną jest tylko notariusz. Wskazanie tylko notariusza jako instytucji obowiązanej świadczy o tym, że w toku procesu legislacyjnego ustawodawca nie wziął pod uwage przepisów ustawy Prawo o notariacie, przewidujących możliwość dokonywania czynności notarialnych przez inne niż notariusz osoby. Może to budzić uzasadnione obawy co do zakresu obowiązków wynikających z nUoP dla poszczególnej osoby dokonującej konkretnej czynności notarialnej ${ }^{19}$. Art. $21 \S 1$ ustawy Prawo o notariacie stwierdza, że

18 Ustawa z dnia 20 sierpnia 1997 r. o Krajowym Rejestrze Sądowym, tekst jednolity:

Dz. U. z 2019 r. poz. 1500 z późn. zm.

19 K. Maj, Obowiazki notariusza..., s. 84. 
„jeżeli notariusz nie może pełnić swych obowiązków, wyznacza na ten czas zastępstwo spośród zastępców notarialnych zatrudnionych w jego kancelarii oraz notariuszy ze wspólnej kancelarii prowadzonej w trybie art. $4 \S 3$, informując o tym prezesa rady właściwej izby albo spośród zastępców notarialnych z wykazu właściwej izby notarialnej oraz notariuszy mających siedzibę kancelarii notarialnej $\mathrm{w}$ tej izbie, $\mathrm{w}$ porozumieniu z prezesem rady właściwej izby". W § 3 ustawy czytamy:

Jeżeli z powodu nieobecności notariusza wynikłej z nieprzewidzianych przyczyn notariusz nie wyznaczył w kancelarii zastępstwa na czas swej nieobecności, zastępstwo wyznacza prezes rady właściwej izby notarialnej. Zastępstwo obejmuje wyłącznie dokonywanie czynności notarialnych, o których mowa w art. 79 pkt 7 [sporządza wypisy, odpisy i wyciągi dokumentów - M.A.K.], oraz wydawanie przyjętych na przechowanie pieniędzy, papierów wartościowych, dokumentów oraz danych na informatycznym nośniku danych, o którym mowa w przepisach o informatyzacji działalności podmiotów realizujących zadania publiczne.

$\S 4$ tej ustawy stanowi, że „w wypadkach, o których mowa w $\S 1$ i 3 do zastępstwa notariusza może być także wyznaczony notariusz emerytow any". W ten sposób mamy do czynienia z różnymi stanami faktycznymi. Określenie zawarte w art. 2 ust. 1 pkt 13 nUoP - notariusze - w zakresie czynności dokonywanych $\mathrm{w}$ formie aktu notarialnego eliminuje z rozważań aplikanta notarialnego, który w tym zakresie nie może wykonywać czynności notarialnych.

Omawiając poszczególne stany faktyczne, jako pierwszy przedstawiony zostanie przypadek, gdy notariusz pozostaje czynnym notariuszem w pełni realizującym zadania notariusza. Wówczas notariusze stają się insty tucjami obowiązanymi w rozumieniu nUoP w zakresie czynności dokonywanych przez nich, tj. w formie aktu notarialnego (kryterium podmiotowo-przedmiotowe $)^{20}$. Warto podkreślić, że notariusze są instytucjami obowiązanymi w zakresie wykonywania czynności notarialnych

20 Obejmujących: a) przeniesienie własności wartości majątkowej, w tym sprzedaż, zamianę lub darowiznę ruchomości lub nieruchomości, b) zawarcie umowy działu spadku, zniesienia współwłasności, dożywocia, renty w zamian za przeniesienie własności nieruchomości oraz o podział majątku wspólnego, c) przeniesienie spółdzielczego własnościowego prawa do lokalu, prawa użytkowania wieczystego oraz ekspektatywy odrębnej własności lokalu, d) wniesienie wkładu niepieniężnego po założeniu spółki, e) zawarcie umowy dokumentującej wniesienie lub podwyższenie wkładów do spółki albo wniesienie 
$\mathrm{w}$ formie aktu notarialnego we wskazanym zakresie przedmiotu tego aktu. W związku z takim zapisem wydawać by się mogło, że w zakresie innych czynności notariusz nie jest instytucją obowiązaną ${ }^{21}$. Niemniej należy zauważyć, że notariusze podlegają także innym uregulowaniom zawartym w nUoP. Przykładem może być zapis art. 76 ust. 2 nUoP, który wprost odnosi się do notariusza jako instytucji obowiązanej, zobligowanej do przekazania Generalnemu Inspektorowi - na jego żądanie - informacji i dokumentów w zakresie innych czynności notarialnych niż wymienione w art. 2 ust. 1 pkt 13 nUoP. Zatem notariusza należy traktować jako instytucję obowiązaną znacznie szerzej, niż by to wynikało wyłącznie z brzmienia zapisu zawartego $\mathrm{w}$ art. 2 ust. 1 pkt 13 nUoP. Tym samym można zauważyć, że definicja notariusza jako instytucji obowiązanej w art. 2 ust. 1 pkt 13 nUoP jest najbardziej adekwatna do obowiązku odnoszącego się do art. 72 ust. 4 nUoP. Jednakże udział notariusza jako instytucji obowiązanej w "systemie przeciwdziałania” nakreślonym nUoP należy traktować znacznie szerzej i odnosić go także do innych obowiązków, jakie zostały nałożone na ten podmiot jako instytucję obowiązaną.

Ponadto zgodnie z art. $72 \mathrm{nUoP}$ (dotyczy on przekazywania do GIIF informacji o transakcjach ponadprogowych) w ust. 4 stwierdza się, że instytucje obowiązane, o których mowa w art. 2 ust. 1 pkt 13 nUoP - a więc notariusze - przekazują Generalnemu Inspektorowi informacje o czynnościach wymienionych w tym przepisie, których równowartość przekracza 15000 euro (chodzi o przedmiot czynności notarialnej). We wskazanym zapisie oraz w zapisie art. 72 ust. 1 nUoP występuje swoista rozbieżność mająca wpływ na zakres przekazywanych do GIIF informacji przez notariuszy. W przy padku art. 72 ust. 1 nUoP wyłączona zostaje instytucja obowiązana w postaci notariusza (instytucje obowiązane, z wyjątkiem instytucji, o których mowa w art. 2 ust. 1 pkt 11, 13 nUoP). A zatem notariusz nie przekazuje informacji o przyjętej wpłacie lub dokonanej wypłacie środków pieniężnych o równowartości przekraczającej 15000 euro oraz wykonanym transferze środków pieniężnych o równowartości przekraczającej 15000 euro (z zawartymi w nUoP wyjątkami). Niemniej już w ust. 4 omawianego artykułu wskazano dla notariuszy obowiązek przekazywania GIIF informacji o czynnościach wymienionych w tym przepisie, których

lub podwyższenie kapitału zakładowego, f) przekształcenie lub połączenie spółek, g) zbycie przedsiębiorstwa, h) zbycie udziałów w spółce.

21 Zob. stanowisko reprezentowane przez K. Maj, Obowiązki notariusza..., s. 85. 
równowartość przekracza 15000 euro. W uzasadnieniu do nUoP wskazano, że art. 72 ust. 4 nUoP jest adresowany do notariuszy i odwołuje się do transakcji, w zakresie których na notariuszach ciążą obowiązki instytucji obowiązanych ${ }^{22}$. Pojęcie „czynności wymienionych w tym przepisie” odnosi się więc nie do art. 72 ust. $1 \mathrm{nUoP}$, lecz do czynności notarialnych wymienionych $\mathrm{w}$ art. 2 ust. 1 pkt 13 nUoP. Oznacza to, że zależnie od kwoty - równowartość przekracza 15000 euro - notariusz powinien przesłać niniejszą informację do GIIF, gdy taka czynność na wskazaną kwotę jest dokonywana $\mathrm{w}$ formie aktu notarialnego. Kolejno ważny jest także przepis art. 72 ust. 5 nUoP. Instytucje obowiązane przekazują informacje $\mathrm{w}$ terminie siedmiu dni od dnia sporządzenia aktu notarialnego - w przypadku informacji, o których mowa w ust. 4. Tym samym ustawodawca wskazał termin, w czasokresie którego notariusz musi się wywiązać ze swojego obowiązku przekazania informacji do GIIF $^{23}$. Dalsze przepisy nUoP rozszerzają zakres przekazywania informacji przez notariuszy do GIIF. Zgodnie z zapisem art. 76 ust. 2 nUoP instytucja obowiązana, o której mowa w art. 2 ust. 1 pkt 13 nUoP (notariusz), na żądanie GIIF przekazuje również informacje i dokumenty w zakresie innych czynności notarialnych niż wymienione $\mathrm{w}$ tym przepisie. Obowiązek ten dotyczy więc wszystkich innych czynności, do których uprawniony jest notariusz, niż dokonania ich $\mathrm{w}$ formie aktu notarialnego w zakresie określonym $\mathrm{w}$ art. 2 ust. 1 pkt 13 lit. a-h. Kwestia dotyczy innego - dedykowanego wyłącznie notariuszom - żądania GIIF niż określonego w art. 76 ust. 1 nUoP. Należałoby sprecyzować, jak można interpretować relacje pomiędzy obowiązkami wynikającymi z żądania GIIF wobec instytucji obowiązanych, określonego w ust. 1a i w ust. 2 art. $76 \mathrm{nUoP}$ w odniesieniu do notariuszy. Wydaje się, że należałoby przyjąć taką interpretację, iż GIIF wobec notariuszy jest uprawniony do żądania zarówno na podstawie ust. 1, jak i ust. 2 art. $76 \mathrm{nUoP}$. Niemniej w takim przypadku niezbędne jest przede wszystkim właściwe określenie okoliczności przez GIIF, co i w jakim zakresie będzie obejmował żądaniem. Wówczas ust. 2 jest swoistym wyróżnieniem

22 Rządowy projekt ustawy o przeciwdziałaniu praniu pieniędzy oraz finansowaniu terroryzmu z dnia 31 stycznia 2018 r., Druk nr 2233, http:/ / www.sejm.gov.pl/Sejm8.nsf/ druk.xsp?nr=2233 [dostęp: 6.03.2019 r.], s. 37.

23 "Notariusz jako instytucja obowiązana jest zobligowany do przekazania w ciągu 7 dni od daty sporządzenia aktu notarialnego informacji o czynnościach notarialnych, o których mowa w art. 2 ust. 1 pkt 13 nUoP, jeżeli ich równowartość przekracza 15000 euro", K. Maj, Obowiązki notariusza..., s. 107. 
notariuszy jako instytucji obowiązanych, wobec których GIIF będzie mógł wystąpić z żądaniem przekazania informacji i dokumentów w zakresie innych czynności notarialnych niż określonych w art. 2 ust. 1 pkt 13 i bezpośrednio związanych z zakresem zadań zawodowych (czynności notarialnych) wykonywanych przez notariuszy. Jak wskazano w uzasadnieniu do projektu nUoP:

Wynikające z art. 76 ust. 2 [nUoP - M.A.K.] uprawnienie Generalnego Inspektora do żądania od notariuszy również informacji i dokumentów w zakresie innych czynności notarialnych niż te, o których mowa w art. 2 ust. 1 pkt 13, wynika z faktu przedmiotowego ograniczenia statusu notariuszy jako instytucji obowiązanych. Jak wskazano powyżej, obowiązki instytucji obowiązanych, w tym te związane ze stosowaniem środków bezpieczeństwa finansowego, ciążą na notariuszach wyłącznie w odniesieniu do katalogu transakcji przeprowadzanych w formie czynności notarialnych określonych w art. 2 ust. 1 pkt 13. Katalog ten zawiera transakcje związane z wyższym prawdopodobieństwem wykorzystania ich do działań mających na celu pranie pieniędzy lub finansowanie terroryzmu. Postępowania analityczne prowadzone przez Generalnego Inspektora mogą implikować konieczność analizy informacji lub dokumentów związanych z czynnościami notarialnymi innymi niż te, w odniesieniu do których na notariuszach ciążą obowiązki instytucji obowiązanych. Dodatkowo więc ta instytucja obowiązana działa także na żądanie podjęte przez Generalnego Inspektora. Brak określonej w art. 76 ust. 2 podstawy prawnej dla Generalnego Inspektora do żądania od notariuszy informacji i dokumentów dotyczących również innych czynności notarialnych innych niż określonych w art. 2 ust. 1 pkt 13 skutkowałby sytuacją, w której Generalny Inspektor mimo powzięcia podejrzeń, że określone transakcje/czynności podjęte w formie czynności notarialnych [innych niż w formie aktu notarialnego - M.A.K.] zostały wykorzystane do procederu legalizacji środków pochodzących z działalności o charakterze przestępczym lub finansowania działalności o charakterze przestępczym [terrorystycznym - M.A.K.], nie byłby uprawniony do pozyskania i wykorzystania w celu realizacji swoich zadań $[\ldots]^{24}$.

Jak można wywnioskować z treści uzasadnienia, podstawa prawna określona w ust. 1 art. 76 nUoP wydawała się ustawodawcy niewystarczająca, aby w oparciu o nią wystąpić do notariusza o dodatkowe „informacje i dokumenty" niezbędne do realizowania przez GIIF jego ustawowych zadań. Niemniej w niektórych przypadkach informacje te mogą się pokrywać z katalogiem określonym w ust. 1, tj. klientów, rodzaju i wielkości wartości majątkowych oraz miejsca ich przechowywania (np. depozyt 
notarialny określony w art. 108 ustawy Prawo o notariacie). Jednakże trudno byłoby zrealizować GIIF żądanie określone w pkt 4 i 5 art. 76 nUoP, kierując je do notariusza (oznaczałoby to żądania informacji i dokumentów odnośnie do stosowania środka bezpieczeństwa finansowego, o którym mowa w art. 34 ust. 1 pkt 4, czyli w zakresie bieżącego monitorowania stosunków gospodarczych klienta czy pozyskania adresów IP, z których następowało połączenie z systemem teleinformatycznym instytucji obowiązanej, oraz czasów połączeń z tym systemem). Takie czynności wychodzą poza zakres działania notariusza. Słusznie więc ustawodawca wyodrębnił uprawnienie żądania przez GIIF pozyskania dodatkowych informacji i dokumentów od notariuszy w odrębnej jednostce redakcyjnej (trudno m.in. prosić o informacje i dokumenty o stosowanych środkach bezpieczeństwa finansowego odnośnie do relacji korespondenckich - art. 45 ust. 1 nUoP, przy których brak jest obowiązku stosowania przez notariuszy środków bezpieczeństwa finansowego). Wprowadzenie dla notariuszy nowego zapisu w art. 2 ust. 1 pkt 13a nUoP wskazuje, że czynności notarialne określone w art. 79 pkt 6a ustawy Prawo o notariacie, czyli raczej czynności notarialne o charakterze materialno-technicznym (prowadzenie rejestru) i podejmowanie związanych z tym czynności powinno być realizowane wobec GIIF na zasadach określonych w art. 72 ust. 1 nUoP. Dodatkowo brak zawarcia odniesienia w art. 76 ust. 2 nUoP do instytucji określonej w art. 2 ust. 1 pkt 13a nUoP nie uniemożliwia uzyskania od notariusza, na żądanie GIIF, dokumentów z "czynności powiązanych z prowadzeniem rejestru akcjonariuszy prostych spółek akcyjnych”. Należy je potraktować jako „inne czynności notarialne niż wymienione w przepisie art. 2 ust. 1 pkt 13 [nUoP - M.A.K.]". Nie oznacza to jednak, że do tych czynności będzie miał zastosowanie art. 72 ust. 4 nUoP. Odnosi się on jedynie do czynności wymienionych w przepisie art. 2 ust. 1 pkt 13 nUoP.

Kolejnym stanem faktycznym jest sytuacja, w której sam notariusz nie może pełnić swoich obowiązków. Powstaje więc pytanie, kto i na jakich zasadach może lub jest $\mathrm{w}$ takiej sytuacji instytucją obowiązaną $\mathrm{w}$ rozumieniu nUoP? Jak wskazano, art. 2 ust. 1 pkt 13 nUoP odnosi się wprost do notariusza, a nie do zastępców notarialnych. Ponadto należałoby rozróżnić sytuację, gdy zastępca notarialny wykonuje swoje zadania w obecności notariusza oraz wtedy, gdy pod nieobecność notariusza wykonuje określone zadania. Należy także zauważyć, że zadania te mogą być wykonywane na podstawie indywidualnego pełnomocnictwa notariusza lub ogólnie wynikać z przepisów prawa (dwie formy wykonywania zastępcy 
notarialnego). Art. 76a § 1 ustawy Prawo o notariacie podaje, że zastępca notarialny może być zatrudniony w kancelarii notarialnej, a ponadto stwierdza, że notariusz może upoważnić zastępcę notarialnego zatrudnionego w swojej kancelarii do wykonywania czynności notarialnych w wypadkach innych niż opisane w art. 21 i art. 22 ustawy Prawo o notariacie. Przepisy art. 22a § 2-4 tej ustawy stosuje się odpowiednio. Tak więc zastępca notarialny może być zatrudniony w kancelarii notarialnej w czasie obecności notariusza i może dokonywać czynności notarialnych zgodnie z udzielonym mu upoważnieniem. W takim przy padku notariusz-instytucja obowiązana musi określić, czy w zakresie wewnętrznych uregulowań zastępca notarialny będzie wykonywał czynności związane z AML/CFT oraz jakie to będą czynności. Istotnym warunkiem zastępowania jest zatrudnienie zastępcy notarialnego przez notariusza w swojej kancelarii. Ponadto nie należy mylić wykonywania czynności notarialnych przez zastępcę notarialnego (notariusza) z wykonywaniem obowiązków związanych z relacjami, jakie zachodzą pomiędzy notariuszem-instytucją obowiązaną a GIIF. W pierwszym przypadku mamy do czynienia z czynnościami notarialnymi (których stroną nie jest GIIF), a w drugim z niejako „sprawozdaniem się", i to z niektórych czynności notarialnych, wobec GIIF (głównie tych, które są wykonywane z inicjatywy notariusza w zakresie wykonywanych przez niego obowiązków wynikających z nUoP). Zatem czynności notarialne pozostają „czynnościami pierwotnymi” wobec czynności realizowanych w związku z obowiązkami nałożonymi na notariusza jako instytucję obowiązaną na podstawie nUoP (jako czynnościami „wtórnymi”). Tym samym wykonywane przez zastępcę notarialnego czynności wynikające z upoważnienia wydanego przez notariusza nie mają w prost charakteru czynności zachodzących w relacji notariusz - GIIF. Dlatego też notariusz, który upoważnia zastępcę notarialnego w zakresie czynności wynikających z obowiązków określonych w nUoP, powinien mieć na względzie własny (ciążący wyłącznie na nim w relacji z GIIF) obowiązek i odpowiedzialność w tej sprawie. Należy zauważyć, że w zakresie czynności notarialnych istotna jest ich prawna skuteczność, a więc to, że zostały one dokonane $\mathrm{w}$ obliczu i przez osobę upoważnioną do ich dokonania. W przypadku czynności AML/CFT-owych istota mieści się w pozytywnym skwitowaniu obowiązku, do jakiego ustawowo jest zobowiązany notariusz. Kwestia ta prawdopodobnie może być ustalona np. w trakcie kontroli wykonywanej przez GIIF lub kontroli wykonywanej przez prezesa sądu apelacyjnego. Niemniej należy zauważyć, że w każdym przypadku 
ustawodawca posługuje się określeniem „notariusz” lub „instytucja obowiązana określona w art. 2 ust. 1 pkt 13 [nUoP - M.A.K.]”. Tym samym w zakresie czynności AML/CFT-owych jako podmiot odpowiedzialny czyni się nie zastępcę notarialnego, lecz notariusza. W konsekwencji to notariusz będzie odpowiadał za niewykonanie obowiązków wynikających z nUoP. Takiemu rozumowaniu towarzyszą inne rozwiązania w prowadzone do nUoP. Przykładem jest tutaj art. 47 ust. 1 nUoP, tj. korzystanie z usług podmiotu trzeciego, gdzie w ust. 2 wprost wskazano, że: „korzystanie z usług podmiotu trzeciego nie zwalnia instytucji obowiązanej z odpowiedzialności za zastosowanie środków bezpieczeństwa finansowego". Podobnie jest w przypadku art. 48 ust. 1 nUoP, w którym ustawodawca daje możliwość powierzenia stosowania środków bezpieczeństwa finansowego. Ustawodawca również w tej kwestii wyraźnie zaznaczył w ust. 2, że: „powierzenie stosowania środków bezpieczeństwa finansowego na zasadach określonych w ust. 1 nie zwalnia instytucji obowiązanej z odpowiedzialności za zastosowanie środków bezpieczeństwa finansowego" ${ }^{\prime 25}$. W przypadku wykonywania czynności z nUoP odnośnie do samego notariusza sprawa wydaje się czytelna. Idąc tym tokiem rozumowania, można uznać, że wydanie przez notariusza - obecnego w kancelarii - pełnomocnictwa do wykonywania czynności podlegających obowiązkowi informacyjnemu w stosunku do GIIF, nie zwalnia notariusza z odpowiedzialności za realizowanie tego obowiązku przez zatrudnionego zastępcę notarialnego. Zatem dla zastępcy notarialnego działającego w czasie obecności notariusza w kancelarii notarialnej, na podstawie upoważnienia udzielonego w trybie art. 76a § 2 ustawy Prawo o notariacie w zw. z art. 22a § 2-4 tej ustawy do dokonywania czynności notarialnych dla zastępcy notarialnego zatrudnionego w kancelarii notarialnej, powinno być udzielone upoważnienie w formie pisemnej na czas określony i wskazywać czynności notarialne, do wykonywania których zastępca został upoważniony. O ile notariusz powierzył mu w jakimś zakresie „przygotowywanie materiałów, informacji i dokumentów" dla GIIF, powinno ono zawierać w tym pełnomocnictwie (lub odrębnym) odzwierciedlenie, jak i sposób „rozliczenia” się z tych wewnętrznych obowiązków zastępcy notarialnego z notariuszem. Należy

25 Dla uściślenia - jest to jednakże możliwe jedynie w sytuacji, gdy na podstawie pisemnej umowy podmiot, któremu powierzono stosowanie środków bezpieczeństwa finansowego, ma być traktowany jako część instytucji obowiązanej. W przypadku notariusza nie może to mieć miejsca. K. Maj, Obowiązki notariusza..., s. 93. 
rozstrzygnąć, czy scedowanie czynności wynikających z obowiązku bycia instytucją obowiązaną stanowi także "upoważnienie do wykonywania czynności notarialnych". Wszak w art. 79 pkt 9 ustawy Prawo o notariacie wskazano, że notariusz dokonuje czynności w postaci: "sporządzania innych czynności wynikających z odrębnych przepisów". Powstaje zatem pytanie: czy dotyczy to także innych czynności wynikających z przepisów nUoP? Wydaje się, że nie ma równości pomiędzy „innymi czynnościami” (art. 79 pkt 9 ustawy Prawo o notariacie) a czynnościami do wykonania na podstawie nUoP. Wynika to przede wszystkim z innej roli, jaką odgrywa instytucja notariusza $\mathrm{w}$ tych dwóch przypadkach i należałoby je traktować odrębnie. Tym samym upoważnienie do wykonywania czynności notarialnych nie jest równoznaczne z upoważnieniem do wykonywania czynności przez notariusza-instytucję obowiązaną na podstawie nUoP. Dlatego też ta odrębność powinna być wyraźnie uwypuklona w upoważnieniu i należałoby się skłonić do przyjęcia stanowiska, że powinno być to upoważnienie odrębne. Zatem tego rodzaju upoważnienie nie podlega dalszym rygorom, np. przesłania do właściwych organów, ale powinno być przedłożone podmiotowi kontrolującemu przestrzeganie przepisów nUoP. Niemniej w konsekwencji takie upoważnienie do wykonywania w imieniu notariusza czynności z nUoP nie powinno mieć mocy prawnej w przypadku nieobecności notariusza w kancelarii notarialnej. O udzielonym upoważnieniu w trybie art. 76a § 2 ustawy Prawo o notariacie w zw. z art. 22a § 2-4 tej ustawy notariusz ma obowiązek niezwłocznie zawiadomić prezesa właściwej izby notarialnej, Ministra Sprawiedliwości oraz prezesa właściwego sądu apelacyjnego, przesyłając tym organom kopie upoważnienia. Przedmiotowe upoważnienie do wykonywania w imieniu notariusza czynności z nUoP daje podstawę do wykonywania przez zastępcę notarialnego czynności notarialnych - określonych $\mathrm{w}$ upoważnieniu - jednocześnie $\mathrm{z}$ notariuszem, w jego imieniu i na jego rzecz. Jednakże nUoP nie precyzuje, czy w zakresie korzystania z usług podmiotu trzeciego, czy też powierzenia stosowania środków bezpieczeństwa finansowego oraz prowadzenia i dokumentowania wyników bieżącej analizy przeprowadzanych transakcji, potrzeba jest forma pisemna. Tym bardziej wydaje się, że ustawa AML-owa nie odnosi się do udzielonego upoważnienia dla zastępującego notariusza. Ponadto należy mieć na uwadze to, że udzielenie pełnomocnictwa dla zastępcy może być powiązane $\mathrm{z}$ wewnętrzną procedurą $\mathrm{w}$ zakresie przeciwdziałania praniu pieniędzy oraz finansowaniu terroryzmu. W takim przypadku należałoby dokonać następujących czynności: opracować i wdrożyć 
wewnętrzną procedurę $\mathrm{w}$ zakresie przeciwdziałania praniu pieniędzy oraz finansowaniu terroryzmu (art. $50 \mathrm{nUoP}$ ) i w niej zawrzeć odpowiednie zapisy regulujące relacje pomiędzy notariuszem a zastępcą notarialnym zatrudnionym przez notariusza (również np. relacje z innymi notariuszami prowadzącymi kancelarię jako spółkę cywilną lub partnerską). Pozwalają na to zapisy ust. 2 art. 50 nUoP, w szczególności w zakresie: zasad upowszechniania wśród pracowników instytucji obowiązanej wiedzy z zakresu przepisów o przeciwdziałaniu praniu pieniędzy oraz finansowaniu terroryzmu, zasad zgłaszania przez pracowników rzeczywistych lub potencjalnych naruszeń przepisów z zakresu przeciwdziałania praniu pieniędzy oraz finansowaniu terroryzmu, zasad kontroli wewnętrznej lub nadzoru zgodności działalności instytucji obowiązanej z przepisami o przeciwdziałaniu praniu pieniędzy oraz finansowaniu terroryzmu i zasad postępowania, które zostały określone $\mathrm{w}$ wewnętrznej procedurze. Oznacza to, że należałoby się liczyć z tym, iż w wyniku wewnętrznej procedury będzie jasne, jakie zadania spoczywają na notariuszu, a jakie na zastępcy notarialnym (ewentualnie na innych notariuszach zatrudnionych w kancelarii). Nie oznacza to natomiast, że oprócz wewnętrznej procedury notariusz nie może udzielić odrębnego pełnomocnictwa (upoważnienia) dla zastępcy notarialnego do wykonywania określonych czynności związanych z przeciwdziałaniem praniu pieniędzy oraz finansowaniu terroryzmu jako przez instytucję obowiązaną, określoną w art. 2 ust. 1 pkt 13 nUoP. Wydaje się wręcz konieczne, by relacje w tym zakresie zawierały jasne stwierdzenia dla obydwu stron, w przy padku gdy notariusz nie chce osobiście w całości realizować zadań wynikających z nUoP. Należy zwrócić uwagę również na to, że będąc zatrudniającym, posiada on oprócz określonych prawem relacji z GIIF także inne obowiązki wobec pracowników wynikające z nUoP. W takim przypadku trzeba uznać, że odnośnie do relacji notariusz - pracownicy na notariuszu spoczywa odpowiedzialność za zrealizowanie obowiązków wobec pracowników kancelarii wynikających z nUoP (np. szkoleniowych). Przy czym wyznaczając jedynie niektóre $\mathrm{z}$ zatrudnionych osób $\mathrm{w}$ kancelarii na odpowiedzialne za działania AML/CFT-owe, tylko te osoby będą podlegały obowiązkowi szkoleniowemu ${ }^{26}$. Ponadto pozostaje do ustalenia kwestia nadzorowania przez

26 Art. 52 ust. 1 nUoP stanowi, że „Instytucje obowiązane zapewniają udział osób wykonujących obowiązki związane z przeciwdziałaniem praniu pieniędzy oraz finansowaniu terroryzmu w programach szkoleniowych dotyczących realizacji tych obowiązków". Tak 
notariusza realizowania przez pracowników kancelarii czynności w ramach obowiązków wynikających z wewnętrznych procedur przeciwdziałania oraz np. z przygotowywania informacji i dokumentów na rzecz GIIF. W tym zakresie również obowiązek wewnętrznego nadzoru nad prawidłowym realizowaniem tych czynności AML-owych spoczywa na notariuszu. Istotnym dokumentem, który powinien ustalić wewnętrzne działania $\mathrm{w}$ tym zakresie, będzie tu także wewnętrzna procedura, mowa o niej w art. $50 \mathrm{nUoP}$.

Zgodnie z treścią zapisów ustawy Prawo o notariacie odróżniono dokonywanie czynności notarialnych przez zastępcę notarialnego na podstawie wydanego przez notariusza upoważnienia od wykonywania przez zastępcę notarialnego zastępstwa pod nieobecność zatrudniającego go notariusza (tryb został określony w art. 21 i 22). Zgodnie z zapisem art. 21 tej ustawy jeżeli notariusz nie może pełnić swoich obowiązków, wyznacza na ten czas zastępstwo spośród zastępców notarialnych zatrudnionych w jego kancelarii oraz notariuszy ze wspólnej kancelarii prowadzonej w trybie art. 4 §3, informując o tym prezesa rady właściwej izby, albo wyznacza zastępstwo spośród zastępców notarialnych z wykazu właściwej izby notarialnej oraz notariuszy mających siedzibę kancelarii notarialnej w tej izbie, w porozumieniu z prezesem rady właściwej izby. Zasadą jest, że osoba zastępująca nieobecnego notariusza $w$ trybie art. $21 \S 1$ ustawy Prawo o notariacie dokonuje w jego zastępstwie wszelkich czynności notarialnych. Ustawodawca nie przewidział tutaj żadnych ograniczeń, w odróżnieniu od zastępstwa w trybie art. $21 \S 2$ (uchylony) i art. 22 ustawy Prawo o notariacie, gdzie wyraźnie ustalił katalog czynności notarialnych, jakich osoba zastępująca notariusza jest władna dokonać. Wyznaczenie zastępstwa w trybie art. 21 $\S 1$ rzeczonej ustawy ma bowiem z założenia zapewnić „powinność czynnej kancelarii", zatem także gwarantować możliwość dokonania czynności - zarówno notarialnych, jak i biurowych czy technicznych ${ }^{27}$. W omawianym przypadku należy odróżnić „zastępowanie nieobecnego notariusza” od tego, kto go zastępuje, w tym katalogu znajduje się bowiem również zastępca notarialny. Słuszne jest stanowisko prezentowane przez

więc zawężono zakres tych osób wyłącznie do tych, które „wykonują obowiązki” (są upoważnione do wykonywania tych obowiązków).

27 Pismo Departamentu Zawodów Prawniczych i Dostępu do Pomocy Prawnej Ministerstwa Sprawiedliwości z dnia 17 lutego 2015 r. skierowane do prezesa Krajowej Rady Notarialnej (znak DZP-IV-620-8/15), s. 1. 
Ministerstwo Sprawiedliwości, że w przypadku art. $21 \S 1$ ustawy Prawo o notariacie chodzi o uzyskanie stanu "czynnej kancelarii” notarialnej. Należy mieć tu na uwadze nie tylko nowe sprawy, ale także podjęte i niedokończone $\mathrm{w}$ chwili zaistnienia zdarzenia będącego podstawą nieobecności notariusza i potrzebę wyznaczenia osób zastępujących. Wydaje się, że w przypadku gdy zastępstwo będzie realizowane przez notariuszy wybranych spośród notariuszy ze wspólnej kancelarii prowadzonej w trybie art. $4 \S 3$ ustawy Prawo o notariacie, sprawa jest zrozumiała i nie wymaga większych wyjaśnień. Zgodnie z trybem określonym w art. 4 § 3 tej ustawy w takim przypadku każdy z notariuszy (wyznaczonych do zastępowania) dokonuje czynności notarialnych we własnym imieniu i ponosi odpowiedzialność za czynności przez siebie dokonane. Tym samym również na notariuszach wyznaczonych na zastępcę nieobecnego notariusza spoczywają wszystkie obowiązki, jakie wynikają z przeciwdziałania praniu pieniędzy oraz finansowaniu terroryzmu zgodnie $\mathrm{z}$ nUoP. Należy pamiętać także o tym, że pomiędzy nieobecnym notariuszem a zastępującym go notariuszem prowadzącym działalność $\mathrm{w}$ trybie art. 4 § 3 ustawy Prawo o notariacie powinna zachodzić etyczna relacja uczciwości. To znaczy w przypadku takiego wyznaczenia, gdy nieobecny notariusz powziął uprzednio informacje o okolicznościach (oprócz czynności, które automatycznie są realizowane $w$ relacji z GIIF) zalegalizowania środków lub sfinansowania działalności terrorystycznej poprzez wykonanie czynności notarialnych, powinien o swoich wątpliwościach poinformować (o ile może to wykonać) tego notariusza, którego wyznaczył na swoje zastępowanie, a który będzie te czynności kontynuował w dalszym czasie zastępowania. Zatem zastępujący notariusz będzie nadal instytucją obowiązaną również dla zakresu zastępowania innego notariusza.

Kolejny przypadek dotyczy wyznaczenia przez nieobecnego notariusza na czas nieobecności zastępców wskazanych spośród zastępców notarialnych zatrudnionych w jego kancelarii. Trzeba uznać, że zastępstwo takie należy potraktować znacznie szerzej, niż jedynie odnosząc je do wykonywania czynności notarialnych. Takie stanowisko reprezentuje też Ministerstwo Sprawiedliwości. Niemniej w przedstawionym stanowisku wskazano także, że do wykonywania zastępstwa, zgodnie z brzmieniem art. $21 \S 1$ ustawy Prawo o notariacie, wystarczy samo wyznaczenie. Odrębne upoważnienie do dokonywania poszczególnych czynności notarialnych nie jest $\mathrm{w}$ tym przypadku nie tylko konieczne, ale nawet możliwe. Na gruncie obowiązujących przepisów zastępca notarialny zastępujący 
nieobecnego notariusza, w odróżnieniu od zastępcy notarialnego działającego na podstawie upoważnienia, dokonuje czynności notarialnych we własnym imieniu (posługując się jedynie pieczęcią zastępowanego notariusza, ale także np. posługując się własnym podpisem elektronicznym). Upoważnienie tymczasem, stanowiąc rodzaj pełnomocnictwa, daje podstawy jedynie do działania $\mathrm{w}$ imieniu i na rzecz mocodawcy $\mathrm{w}$ zakresie określonym w upoważnieniu ${ }^{28}$. Jednakże mając na uwadze odpowiedzialność zarówno za wykonywanie czynności notarialnych, jak i czynności wykonywanych przez notariusza w ramach realizacji obowiązków przeciwdziałania praniu pieniędzy oraz finansowaniu terroryzmu, powinna być zachowana forma pisemna swoistego wewnętrznego "aktu wyznaczenia”. Powinno to dotyczyć zarówno wyznaczenia notariusza, jak i zastępcy notarialnego. Jeszcze raz należy podkreślić, że ustaw odawca nie wprowadził do zakresu instytucji obowiązanych ani zastępcy notarialnego, ani zastępującego notariusza pod jego nieobecność. Taka sytuacja nastręcza szeregu trudności. Biorąc za podstawę w założeniu ścisłą interpretację przepisów ustawy nUoP, mogą nastąpić wskazane poniżej trudności:

1) Jeżeli notariusz nie może pełnić swych obowiązków, zgodnie z art. $21 \S 1$ ustawy Prawo o notariacie, do realizowania obowiązków AML/CFT będzie mógł wyznaczyć wyłącznie notariuszy ze wspólnej kancelarii prowadzonej w trybie art. 4 § 3 tej ustawy, informując o tym prezesa rady właściwej izby, albo notariuszy mających siedzibę kancelarii notarialnej w tej izbie, w porozumieniu z prezesem rady właściwej izby. Nie będzie mógł natomiast wyznaczyć: zastępców notarialnych zatrudnionych w jego kancelarii albo osoby spośród zastępców notarialnych z wykazu właściwej izby notarialnej.

2) Jeżeli z powodu nieobecności notariusza wynikłej z nieprzewidzianych przyczyn notariusz nie wyznaczył w kancelarii zastępstwa na czas swej nieobecności, zastępstwo wyznacza zgodnie $\mathrm{z}$ art. $21 \S 3$ ustawy Prawo o notariacie prezes rady właściwej izby notarialnej. W zakresie obowiązków AML/CFT, w tym głównie wynikających z art. 76 ust. 2 nUoP, wyznaczonym może być wyłącznie inny notariusz, nie zaś zastępca notarialny. 
Niemniej należałoby przyjąć $\mathrm{w}$ tym przypadku dość racjonalne podejście i wykładnię celowościową relacji (prawidłowych), jakie powinny zachodzić pomiędzy notariuszem-instytucją obowiązaną a GIIF. Wówczas trzeba by spojrzeć całościowo na konstrukcję systemu przeciwdziałania, jaką wprowadzono w nUoP, w szczególności na to, że jednostka analityki finansowej obsługująca GIIF przetwarza informacje uzyskiwane od instytucji obowiązanych, lecz może również pozyskiwać od tych instytucji informacje i dokumenty, kierując do nich żądania w trybie określonym $\mathrm{w}$ art. $76 \mathrm{nUoP}$. Informacje te podlegają analizie, ale także GIIF przekazuje je uprawnionym jednostkom współpracującym na zasadach i w zakresie określonym nUoP. Tym samym, gdyby przyjąć, że zobowiązanym do wykonywania obowiązków i adresatem kierowanych żądań będzie - w przypadku określonym w art. $21 \S 1$ ustawy Prawo o notariacie - notariusz, a nie zastępca notariusza (również pod jego nieobecność i w przypadku niewyznaczenia zastępstwa), może nastąpić paraliż informacyjny niekorzystny głównie dla GIIF. Dlatego też mimo braku wprowadzenia jako instytucji obowiązanej wyznaczonego, zastępującego notariusza zastępcę notarialnego pod jego nieobecność - wskazanego w trybie art. 21 § 1 ustawy Prawo o notariacie - nie można uznać takiej osoby za instytucję obowiązaną i uprawnioną do wykonywania relacji z GIIF na podstawie nUoP. Relacja ta powinna w pełni uwzględniać obowiązki określone nUoP, tym samym pod nieobecność notariusza powinien obowiązki te wykonywać nie zastępca notarialny, a inny notariusz. Należy mieć to na uwadze w momencie realizowania aktu „wyznaczania” przez notariusza lub prezesa izby. Niemniej wyznaczenie zastępcy notarialnego zgodnie z art. 21 ust. 1 i 2 ustawy Prawo o notariacie pozostaje zgodne $z$ aktualnymi przepisami. Brak podmiotu zdefiniowanego jako instytucja obowiązana może sparaliżować napływ informacji dla GIIF w przypadku wyznaczenia zastępcy notarialnego. Natomiast ograniczanie możliwości wyznaczenia zastępcy notarialnego, w przypadku braku notariusza, z uwagi na na brak możliwości wykonywania obowiązków AML-owych jest niedopuszczalne pod względem wykonywania prawa określonego w ustawie Prawo o notariacie. Podczas wyznaczania jednak notariusz, tak jak i prezes izby, powinni zdawać sobie sprawę z tego, że status notariusza wynika także z innych przepisów niż z przywołanej ustawy, a w omawianym przypadku konkretnie z nUoP. Przy czym, jak zaznaczono uprzednio, gdy jest to wskazany notariusz, wykonuje on czynności AML-owe tak, jakby działał we własnym imieniu i ponosi odpowiedzialność za dokonane przez siebie 
czynności. Nie wydaje się niemożliwe to, aby nieobecny notariusz nie mógł wyznaczyć $\mathrm{z}$ jednej strony zastępcy notarialnego w zakresie czynności notarialnych, a z drugiej strony innego notariusza do wykonywania obowiązków pod jego nieobecność, w zakresie określonym nUoP. Taki wybór „wyznaczenia" może nastąpić z własnej inicjatywy i realizacji (wspólna kancelaria), ale także $\mathrm{w}$ porozumieniu z prezesem rady właściwej izby, gdy takiej możliwości nie ma. Podjęcie tego rodzaju czynności „wyznaczenia" daje w pełni art. $21 \S 1$ ustawy Prawo o notariacie, przy czym możliwość wystąpienia takiej sytuacji - nieobecności notariusza i wyznaczenia zastępstwa - powinna również uwzględniać wewnętrzna instrukcja. W szczególności, że $\mathrm{w}$ takim przypadku nie jest wymagane jakiekolwiek upoważnienie, a jedynie wyznaczenie. Ponadto zastępca notarialny zastępujący nieobecnego notariusza - o ile wyłącznie taka osoba będzie wyznaczona pod nieobecność notariusza - w relacjach z GIIF powinien zdawać sobie sprawę z tego, że nie może on zarówno powoływać się na upoważnienie, jak i zasłaniać się upoważnieniem, ponieważ nie jest uprawniony do wykonywania obowiązków wynikających z nUoP. Działa wówczas ,jjak nieobecny notariusz". Zapisy art. $21 \S 1$ ustawy Prawo o notariacie pozwalają na to, by podjąć działania w kierunku eliminacji sytuacji, w której „nieobecny notariusz" powoduje "nieobecność” obowiązków informacyjnych wobec GIIF, mimo że w danej kancelarii generowane są zdarzenia podlegające takiemu obowiązkowi. Niemniej należałoby się skłonić ku stanowisku, że zastępca notarialny zastępujący nieobecnego notariusza w relacjach z GIIF powinien być nieograniczony w przesyłaniu informacji z własnej inicjatywy (art. 72 ust. $4 \mathrm{nUoP}$ ), ale aby takie postępowanie mogło mieć miejsce i być prawnie realizowalne, wymaga wpisania jako instytucji obowiązanej do katalogu art. 2 ust. 1 pkt 13 także zastępcy notarialnego, jeżeli został wyznaczony do wykonywania zadań notariusza w przypadku jego nieobecności. Dodatkowo w tym kontekście przedstawionej propozycji należy zauważyć, że zgodnie z art. 76 § 1 ustawy Prawo o notariacie zastępcą notarialnym jest osoba, która uzyskała pozytywny wynik z egzaminu notarialnego i złożyła ślubowanie. Minister Sprawiedliwości niezwłocznie po ustaleniu wyniku egzaminu notarialnego wydaje zaświadczenie o uzyskaniu statusu zastępcy notarialnego, które doręcza zastępcy notarialnemu i prezesowi rady izby notarialnej właściwej dla miejsca zamieszkania zastępcy notarialnego. Na podstawie takiego zaświadczenia prezes rady właściwej izby notarialnej odbiera ślubowanie, a następnie umieszcza zastępcę notarialnego w wykazie zastępców notarialnych danej izby. Pełni 
on w więc w omawianym przypadku ,rolę notariusza bez własnej kancelarii". Do przedstawionego poglądu skłania również to, że w rzeczywistości w relacji notariusz/instytucja obowiązana a GIIF chodzi niejako o „sprawozdanie się z niektórych czynności notarialnych" wykonywanych w kancelarii, nie zaś z funkcjonowania kancelarii jako takiej. Tak więc należy domniemywać, że zastępca notarialny posiada określoną wiedzę merytoryczną w zakresie czynności, do jakich jest zobowiązany i upoważniony sam notariusz. Tym samym nie może zakrywać się niewiedzą o potrzebie realizowania obowiązków w obszarze przeciwdziałania praniu pieniędzy oraz finansowaniu terroryzmu. Zastępca notarialny $\mathrm{w}$ takim przypadku będzie działał w imieniu własnym. Przepisy wymagają jedynie poinformowania prezesa rady właściwej izby notarialnej o wyznaczeniu zastępstwa w trybie art. 21 § 1 ustawy Prawo o notariacie odnośnie do zadań wynikających $\mathrm{z}$ przeciwdziałania praniu pieniędzy oraz finansowaniu terroryzmu. Zasadne jest zatem przyjęcie poglądu, że zastępca notarialny zatrudniony w kancelarii notarialnej wyznaczony do wykonywania zastępstwa (zastępowania) notariusza $w$ trybie art. $21 \S 1$ ustawy Prawo o notariacie nie korzysta z upoważnienia udzielonego w trybie art. 76a tej ustawy. Ulega ono na ten czas niejako „zawieszeniu”, posiadając z definicji węższy zakres, skoro dotyczy jedynie czynności notarialnych, nieobejmujących czynności biurowych czy technicznych ${ }^{29}$. Tak więc zastępca notariusza zastępujący nieobecnego notariusza mógłby - przy zmianie przepisów - realizować nie tylko czynności wynikające z zakresu określonego w art. 2 ust. 1 pkt 13 nUoP, ale również wynikające $\mathrm{z}$ art. 76 ust. 2 nUoP w relacji z GIIF. Wydaje się, że przedstawiona interpretacja pozostaje $\mathrm{w}$ aktualnym stanie prawnym przynajmniej racjonalna. Wyznaczając wyłącznie na czas nieobecności notariusza zastępcę notarialnego, niemożliwe jest w jakikolwiek sposób realizowanie obowiązków AML/CFT-owych w danej kancelarii, ale przede wszystkim przesyłanie informacji i przekazywanie ich do GIIF, co jest głównym założeniem dla aktywności w relacji notariusz GIIF. Nadzór nad realizowaniem czynności przez zastępcę notarialnego w trybie art. $21 \S 1$ ustawy Prawo o notariacie musi podlegać takiemu samemu nadzorowi, jaki jest realizowany przez prezesa sądu apelacyjnego nad notariuszem. Akt wyznaczenia zastępcy nie może uniemożliwiać zarówno realizowanie obowiązków nadzorczo-kontrolnych przez GIIF, jak i przez podmiot określony w art. 130 ust. 2 pkt 1 lit. d nUoP. W takiej

29 Tamże, s. 3-4. 
sytuacji jednak zastępca nie może być potraktowany "jak notariusz" w rozumieniu AML-owym. Jeżeli warunki te nie mogą być spełnione, to aktualnie występuje dość poważna podmiotowa luka prawna w systemie przeciwdziałania ML/FT w zakresie podmiotowym i przedmiotowym, działająca przede wszystkim na niekorzyść samego GIIF. Swoje wątpliwości przedstawił również K. Maj, wskazując, że zastępca może użyć tylko własnego podpisu elektronicznego. Nie jest jasne, jak system teleinformatyczny GIIF będzie traktował takie zgłoszenie ${ }^{30}$. Racjonalnym rozwiązaniem byłoby jedynie takie, że w sytuacji realizowania czynności przez zastępcę notarialnego $\mathrm{w}$ trybie art. 21 \& 1 ustawy Prawo o notariacie należałoby go uznać technicznie za „nową instytucję obowiązaną", podlegającą zgłoszeniu w trybie art. $77 \mathrm{nUoP}$. Nie jest to jednak możliwe, ponieważ GIIF nie posiada uprawnienia do nadawania statusu instytucji obowiązanej innymi podmiotom niż wymienione $\mathrm{w}$ ustawie. Ewentualnie można byłoby rozpatrywać zastosowanie wobec zastępcy notarialnego art. $17 \mathrm{nUoP}{ }^{31}$. Przytoczona argumentacja opiera się jednak jedynie na tzw. racjonalnym podejściu, dlatego też w przyszłości kwestia statusu zastępcy notarialnego działającego $\mathrm{w}$ trybie art. 21 § 1 ustawy Praw o notariacie powinna zostać jasno uregulowana także w nUoP. Obecnie, zgodnie z przytoczonymi przepisami, z chwilą objęcia kancelarii notarialnej przez zastępcę notarialnego, który zastępuje nieobecnego notariusza, sytuacja ta może być potraktowana jako „przerwa w byciu instytucją obowiązaną”, co pozostaje $\mathrm{w}$ pełni nielogicznym i negatywnym rozwiązaniem, zwłaszcza że art. 2 ust. 1 pkt $13 \mathrm{w}$ zw. $\mathrm{z}$ art. 72 ust. 4 wskazuje na potrzebę automatycznego przekazywania informacji z dokonanych czynnościach $\mathrm{w}$ formie aktu notarialnego opiewających na przedmiot powyżej 15000 euro. Pozostawia to w pełni niekomfortową sytuację dla „nieobecnego notariusza”, ,zastępcy notarialnego, który zastępuje nieobecnego notariusza” oraz GIIF.

$30 \quad$ K. Maj, Obowiazki notariusza..., s. 85

31 Art. 17 ust. 1 nUoP: „Generalny Inspektor może zawierać porozumienia z podmiotami innymi niż instytucje obowiązane $\mathrm{w}$ zakresie gromadzenia informacji istotnych dla realizacji jego zadań. W porozumieniu określa się zakres, formę i tryb przekazania informacji". 


\section{Zakończenie}

Nie ulega wątpliwości, że notariusze powinni być jedną z instytucji obowiązanych w rozumieniu nUoP. Zadania nałożone na instytucje obowiązane nie polegają jedynie na zgłaszaniu określonych informacji, ale także na podejmowaniu czynności prewencyjnych uniemożliwiających dokonanie przestępstwa z art. 165a czy art. 299 Kodeksu karnego. Takie zadanie spoczywa także na notariuszach. Udzielenie pełnomocnictwa przez obecnego notariusza dla pracownika kancelarii nie zwalnia go z obowiązków i odpowiedzialności określonych w przepisach nUoP. Problematyczne pozostają kwestie odpowiedzialności i obowiązków wyznaczonego zastępcy notarialnego pod nieobecność notariusza. Tym samym należałoby poszerzyć zakres podmiotowy instytucji obowiązanych, obejmując nim również zastępcę notariusza. Powinno to jednak dotyczyć pewnej wyjątkowej sytuacji (art. 21 § 1 ustawy Prawo o notariacie), w której działa on „jak notariusz". Inaczej niemożliwe jest realizowanie obowiązków AML/CFT-owych przez zastępcę notariusza, co działa na szkodę bezpieczeństwa i stanowi poważną lukę w systemie przeciwdziałania w kraju. Kwestia ta w związku z brakiem opcji narodowej powinna pozostawać w zgodności z przepisami UE.

\section{Bibliografia}

\section{Źródła}

\section{Akty prawne}

Dyrektywa Parlamentu Europejskiego i Rady (UE) 2015/849 z dnia 20 maja 2015 r. w sprawie zapobiegania wykorzystywaniu systemu finansowego do prania pieniędzy lub finansowania terroryzmu, zmieniająca rozporządzenie Parlamentu Europejskiego i Rady (UE) nr 648/2012 i uchylająca dyrektywę Parlamentu Europejskiego i Rady 2005/60/WE oraz dyrektywę Komisji 2006/70/ WE (Tekst mający znaczenie dla EOG), Dz. Urz. UE L 141/73 z 5.6.2015.

Rządowy projekt ustawy o przeciwdziałaniu praniu pieniędzy oraz finansowaniu terroryzmu z dnia 31 stycznia 2018 r., Druk nr 2233, http:/ /www.sejm. gov.pl/Sejm8.nsf/druk.xsp?nr=2233 [dostęp: 6.03 .2019 r.].

Ustawa z dnia 14 lutego 1991 r. - Prawo o notariacie, tekst jednolity: Dz. U. z 2020 r. poz. 1192. 
Ustawa z dnia 20 sierpnia 1997 r. o Krajowym Rejestrze Sądowym, tekst jednolity: Dz. U. z 2019 r. poz. 1500 z późn. zm.

Ustawa z dnia 15 września 2000 r. - Kodeks spółek handlowych, tekst jednolity: Dz. U. z 2020 r. poz. 1526.

Ustawa z dnia 1 marca 2018 r. o przeciwdziałaniu praniu pieniędzy oraz finansowaniu terroryzmu, Dz. U. z 2020 r. poz. 971 z późn. zm.

\section{Orzecznictwo}

Wyrok NSA z dnia 27 września 2018 r., II GSK 2831/16, http:/ / orzeczenia.nsa. gov.pl/doc/E7B22AC058 [dostęp: 20.03.2019 r.].

Wyrok NSA z dnia 8 stycznia 2019 r., II GSK 4441/16, http:/ / orzeczenia.nsa.gov. pl/doc/81B0822860 [dostęp: 20.03.2019 r.].

\section{Pozostałe źródła}

Pismo Departamentu Zawodów Prawniczych i Dostępu do Pomocy Prawnej Ministerstwa Sprawiedliwości z dnia 6 czerwca 2014 r. skierowane do prezesa Rady Izby Notarialnej w Krakowie (znak DZP-IV-620-84/14).

Pismo Departamentu Zawodów Prawniczych i Dostępu do Pomocy Prawnej Ministerstwa Sprawiedliwości z dnia 17 lutego 2015 r. skierowane do prezesa Krajowej Rady Notarialnej (znak DZP-IV-620-8/15).

\section{Literatura}

Holocher J., Bezpieczeństwo obrotu prawno-finansowego. Obowiąki notariusza $w$ świetle ustawy o przeciwdziałaniu praniu pieniędzy oraz finansowaniu terroryzmu, Kwartalnik Prawa Publicznego 2015, t. 13, nr 2.

Maj K., Obowiązki notariusza w nowej ustawie o przeciwdziałaniu praniu pieniędzy i finansowaniu terroryzmu, Krakowski Przegląd Notarialny 2018, t. 3, nr 1.

\section{Netografia}

https://e-konsultantprawny.pl/pl/wiki/page/przystapienie-nowego-partnera-do-spolki-partnerski/ [dostęp: 4.03.2019 r.].

https://www.infor.pl/prawo/encyklopedia-prawa/s/272157,Spolka-partnerska.html [dostęp: 4.03.2019 r.].

Public Consultation on the Draft Risk-Based Approach Guidance for Legal Professionals, Accountants and Trust and Company Service Providers, oficjalna strona FATF: https:/ / www.fatf-gafi.org/publications/fatfgeneral/documents/public-consultation-guidance-tcsp.html [dostęp: 2.04.2019 r.].

Studziński W., Przystapienie do spótki cywilnej, https://mojafirma.infor.pl/spolki/ spolki/spolka-cywilna/691532,Przystapienie-do-spolki-cywilnej.html [dostęp: 20.03.2019 r.]. 


\section{Streszczenie}

Jedną z instytucji obowiązanych zobligowanych do przekazywania informacji na rzecz Generalnego Inspektora Informacji Finansowej o podejrzeniu prania pieniędzy oraz finansowania terroryzmu jest notariusz. Nowa ustawa z dnia 1 marca 2018 r. o przeciwdziałaniu praniu pieniędzy oraz finansowaniu terroryzmu (nUoP) nie przewidziała jako instytucji obowiązanej zastępcy notariusza. Instytucja ta została wprowadzona do ustawy z dnia 14 lutego $1991 \mathrm{r}$. - Prawo o notariacie $\mathrm{w}$ art. 76 . W niektórych sytuacjach zastępca notarialny wykonuje zadania "jak notariusz", tym samym powinien być również zobligowany do wykonywania obowiązków określonych w nUoP. Nie oznacza to jednak, że w tej sytuacji pozostaje on także „instytucją obowiązaną w rozumieniu nUoP”. Ta swoista dysfunkcja pomiędzy wskazanymi przepisami, powodująca niepewność sytuacji prawnej oraz lukę w systemie AML/CFT, wymusza potrzebę ujednolicenia rozwiązań i ustanowienia również zastępcy notarialnego - instytucją obowiązaną.

Słowa kluczowe: notariusz, zastępca notarialny, kancelaria notarialna, instytucja obowiązana, przeciwdziałanie praniu pieniędzy, przeciwdziałanie finansowaniu terroryzmu

\section{NOTARY PUBLIC AS AN OBLIGATED INSTITUTION WITHIN THE MEANING OF THE ACT ON COUNTERACTING MONEY LAUNDERING AND FINANCING OF TERRORISM (DISCUSSION ON SELECTED ISSUES)}

\section{Summary}

There is no doubt that notaries should be one of the obligated institutions within the meaning of Act on Counteracting Money Laundering and Financing Terrorism. The tasks imposed on the obligated institutions are not limited only to reporting certain information, but they also include taking preventive actions that make it impossible to commit an offense under article 165a or 299 of the Criminal Code. Such a task also rests with notaries in regard to their status based not only on IV DAML and the 1 March 2018 Act on Counteracting Money Laundering and Financing Terrorism but also on the final of the FATF guidelines. The 1 March 2018 Act on Counteracting Money Laundering and Financing Terrorism has adopted a more rational model of cooperation between notaries and the General Inspector (subject/subject) in relation to the previous solutions. Granting a power of attorney by a current notary to a person employed in a law firm without the rights of a notary public, e.g. an employee (without the right to perform notarial activities) does not exempt from the duties and liability of the notary himself on the basis of the 1 March 2018 Act on Counteracting Money Laundering 
and Financing Terrorism finance regulations. To the contrary, the problems of responsibility and duties remain based on the action of the appointed notary's deputy in the absence of a notary public. Thus, one should consider whether the scope of being an obligated institution should not extend to the deputy notary as well, since this occupation owns and exercises a number of powers identical to the activities of the notary himself and in a unique situation (article 21-1 the Law on Notarial), it operates "like a notary public". This issue, due to the lack of national option, should be in compliance with EU regulations.

Key words: notary, deputy notary, notary office, obligated institution, counteracting money laundering, counteracting the financing of terrorism

\section{НОТАРИУС КАК ОБЯЗАННОЕ ЛИЦО ПО СМЫСЛУ ЗАКОНА О ПРОТИВОДЕЙСТВИИ ОТМЫВАНИЮ ДЕНЕГ И ФИНАНСИРОВАНИЮ ТЕРРОРИЗМА (ОБСУЖДЕНИЕ НЕКОТОРЫХ ВОПРОСОВ)}

\section{Резиме}

Одним из обязанных мии, которые по закону обязательно должны предоставлять Генеральному инспектору финансовой информации сведения относительно подозрений в отмывании денег и финансировании терроризма, является нотариус. Новый Закон от 1 марта 2018 года о противодействии легализации преступных доходов и финансированию терроризма (НЗоП) не предусматривает в качестве обязанного лица - лица замещающего нотариуса. Это лицо было внесено в Закон о нотариате от 14 февраля 1991 года в ст. 76. В некоторых ситуациях лицо замещающее нотариуса выполняет задачи «как нотариус», поэтому оно также должно быть обязано выполнять обязанности, указанные в НЗоП. Это, однако, не означает, что в этой ситуации оно также остается «обязанным лицом по смыслу НЗоП». Эта своеобразная дисфункция между указанными положениями, вызывающая неопределенность правовой ситуации и пробел в системе противодействия ML/FT (анг. money laundering / financing of terrorism), вынуждает необходимость стандартизировать решения, а также установить лиц замещающих нотариуса - обязанным лицом.

Ключевые слова: нотариус, лицо замещающее нотариуса, нотариальная контора, обязанное лицо, противодействие отмыванию денег, противодействие финансированию терроризма 
